\title{
Peertechz
}

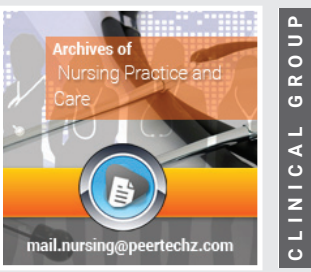

Review Article

\section{Nursing care in the patient with epilepsy/seizures}

\section{Liuba Hernandez Toledo ${ }^{1}$, Maria de los Angeles Peña Figueredo², Lisette Miranda Lara ${ }^{3}$ and Juan E Bender del Busto $4 *$}

${ }^{1}$ Bachelor's Degree in Nursing, International Center of Neurological Restoration (CIREN), Havana, Cuba ${ }^{2}$ Bachelor's Degree in Nursing, Master in Satisfactory Longevity, International Center of Neurological Restoration (CIREN), Havana, Cuba

${ }^{3}$ Bachelor's Degree in Nursing, Master in Infectious Diseases, International Center of Neurological Restoration (CIREN), Havana, Cuba

${ }^{4}$ Philosopher Doctor, 2nd Degree Specialist in Neurology, Full Professor and Researcher, Consultant Professor, International Center of Neurological Restoration, Havana, Cuba
Received: 17 September, 2020

Accepted: 25 September, 2020

Published: 28 September, 2020

*Corresponding author: Juan Enrique Bender del Busto, MD, PhD, Philosopher Doctor, 2nd Degree Specialist in Neurology, Full Professor and Researcher, Consultant Professor, International Center of Neurological Restoration, Neurology Department, Havana, Cuba, Tel: +53 52524480; E-mail: jebender@infomed.sld.cu ORCID: https://orcid.org/0000-0002-0422-2562 Keywords: Epilepsy; Nursing care; Comprehensive management; Preventable complications

https://www.peertechz.com

Check for updates

\section{Abstract}

Epilepsy is considered to be as old as humanity itself and one of the most common Central Nervous System disorders. It has been known since ancient times and is considered a modern disease. It is a global health problem and is affected by more than 50 million people, most of them from developing countries and with psychobiological consequences and even the risk of death, as part of its complications. Comprehensive management is necessary, which includes preventive / prophylactic, pharmacological and non-pharmacological treatment and, therefore, the training of nursing staff in specialized protocols is essential, to ensure adequate patient management, adequate quality of care and avoid complications preventable, which is set out in the document.

\section{Introduction}

Epilepsy is considered as old as humanity itself and can occur in anyone without distinction of age, sex, race, social origin or geographical characteristics. It is one of the most frequent Central Nervous System (CNS) disorders and for some the second neurological disease [1].

It is the fourth cause of neurological disability (7.9\%), after Migraine (8.3\%), Dementias (12.0\%) and Cerebrovascular Disease (55\%) [2].

It is currently considered by the International League Against Epilepsy (ILAE) and the International Bureau for Epilepsy (IBE), as a disease and not a disorder [3].

The most frequent age of onset is childhood and adolescence, however, as longevity increases on the planet, it has been seen that the incidence and prevalence of this disorder also increases in the elderly [4].

It has been known since ancient times, by the name of
"Morbo Sacro" or "Sacred Disease" and the "ataques" or epileptic seizures with the term "epilambaneim" which means "attack", " surprise", ". seize of", or " fall on itself", from which derives the term through which it is currently known: Epilepsy.

Hippocrates first described it in his book "The Sacred Disease" [5].

According to the Pan American Health Organization (PAHO), epilepsy is, in turn, a global public health problem and a clinical condition with self-referral in up to $50 \%$ of cases. According to reports from the World Health Organization (WHO), an estimated 50 to 69 million people suffer from this disease, the majority living in developing countries, where the quality of life is worse and the incidence of infections of the nervous system central nervous system (CNS) is greater, and it can be asserted that epilepsy affects $1-2 \%$ of the population [6-10].

This disease can also be a cause of death, a danger that is not taken into account and could be preventable, and can 
reduce life expectancy, especially in patients with structural etiology epilepsy.

International statistics show annual mortality rates of 2.1 per 100,000 inhabitants per year, varying from 1 to 8 in the different countries [11-15].

The first treatments included everything from exorcism to the practice of bloodletting [16].

However, modern and scientific therapy dates back to the 19th century with the accidental discovery of bromide salts. From then on, a variety of drugs were incorporated into the therapeutic arsenal of this disease and more recently in the management of it, different techniques and alternative methods [17-20].

Recently, it is considered that the treatment should be comprehensive, therefore it is conceived as prophylactic / preventive, pharmacological and non-pharmacological, in which the management and care of the nursing staff is essential [2]. That is why we intend in this context to describe from a scholastic point of view, the aspects to be taken into account by the nursing staff, when faced with a patient with the diagnosis of epilepsy, or the same present epileptic-type cerebral seizures and attempts are made to minimize the devastating aspects of this disease.

\section{Materials and methods}

The document aims to summarize the scientific evidence available regarding nursing care in patients with epileptic seizures, whether they have a diagnosis of epilepsy or not in order to guide the nursing staff in the management of these patients. To prepare it, the search engine Google Academic and the descriptors epileptic seizures, epilepsy, and nursing care were used.

The information sources were the databases: Medline / PubMed, Scielo / Scopus and Medscape. The search was carried out using keywords, in English or Spanish, without a time limit, and all types of publications. The 40 articles related to epilepsy, seizures and nursing care were selected, which were considered of higher scientific quality and the reviews were prioritized. Articles with similar scientific information were excluded.

\section{Results}

\section{Concepts in epilepsy}

The International League Against Epilepsy (ILAE) and the World Health Organization (WHO) from 1973 defined Epilepsy as a chronic and recurrent condition of paroxysmal seizures (epileptic seizures), triggered by abnormal electrical discharges that have varied clinical manifestations of multifactorial origin and associated with paraclinical disorders (electroencephalographic abnormalities) that present in an unprovoked manner [2].

Thirty years later, the conceptual definition of seizures and epilepsy according to the 2005 report of the International
League Against Epilepsy (ILAE) working group, specifies that the transient appearance of signs and / or symptoms is called "seizure" caused by excessive or simultaneous abnormal neuronal activity in the brain and that epilepsy is a brain disorder characterized by a continuous predisposition to the appearance of epileptic seizures and by the neurobiological, cognitive, psychological and social consequences of this disease. The definition of epilepsy requires the presence of at least one epileptic seizure [21].

Recently (2014) a group of experts from the ILAE has published, with the consensus of the epileptologists from the different chapters, the operational (practical) clinical definition of epilepsy:

It is considered by consensus that epilepsy is a brain disease that is defined by any of the following circumstances:

1. At least two unprovoked (or reflex) seizures $>24$ hours apart.

2. An unprovoked (or reflex) seizure and a probability of presenting new seizures during the next 10 years similar to the general risk of recurrence (at least $60 \%$ ) after the appearance of two unprovoked seizures.

\section{Diagnosis of an epilepsy syndrome.}

According to these criteria, a patient who has suffered a seizure has epilepsy and whose brain, for whatever reason, shows a pathological and continued tendency to suffer recurrent seizures. This trend can be imagined as a pathological reduction in the seizure threshold compared to people who do not have the disease [22].

Epileptic seizures appear suddenly and unexpectedly in almost all occasions, both in patients with known epilepsy and in those with an initial seizure. They can occur in any place, situation and with a short or long duration in the form of status epilepticus; therefore, all health professionals must be familiar with the actions to be carried out in the event of an epileptic seizure, since an inappropriate action can have irreparable consequences [2].

Due to the complexity of this pathology, due to the social involvement that it presents and its psychobiological and even economic consequences, the patient with epilepsy and therefore, a carrier of epileptic seizures, must be managed with a multidisciplinary nature $[23,24]$.

Therefore, specific training in epilepsy for nursing staff is essential, and it must be based on specialized protocols and having a trained team is of vital importance to ensure correct patient management, adequate quality of care and avoid preventable complications $[25,26]$.

\section{Evaluation}

The evaluation of the epileptic seizures presented by hospitalized patients will be carried out using a model established for this purpose and which includes the following aspects (Table 1) [27]: 
Table 1: Epileptic Seizure Reporting Model.

No. Clinical History:

Name of patient:

Age:

Gender:

Diagnosis on admission:

Previous epileptic seizures:

Type of seizure:

Duration of seizure:

Conduct followed:

Evolution of seizures:

Accidents that occurred during the seizure:

Reports:

Name and surname:

\section{Controls}

The control of this procedure will be carried out through the review in the inspections that are carried out in each Clinic by the Supervisor.

\section{Precipitating factors}

In this regard, the common precipitating factors of epileptic seizures will be taken into account, such as $[2,28]$ :

- Stress, sleep deprivation

- Fatigue and exercise

- Illumination

- Non-compliance with medical treatment

- Medications that can lower the seizure threshold

- Metabolic factors, Menstruation (catamenial epilepsy), fever (infection) and hyperventilation.

Action in front of an epileptic seizure in the hospital environment $[29,30]$.

In this section we refer to the nursing action on those people who have a focal or generalized seizure and who are in the emergency service or admitted, in which case we may know from their previous history, the risk they have of suffering an epileptic seizure or its history is unknown [31].

That is, we can be in the presence of a patient known as epileptic or who has epileptic seizures, without a previous history of the disease.

Focal and generalized onset seizure in the hospital environment (Figure 1) [32,33]:

- The doctor will be notified.

- The patient will be placed in a horizontal plane and care will be taken that he does not receive trauma to the skull, with the head tilted and the clothing lopsided.

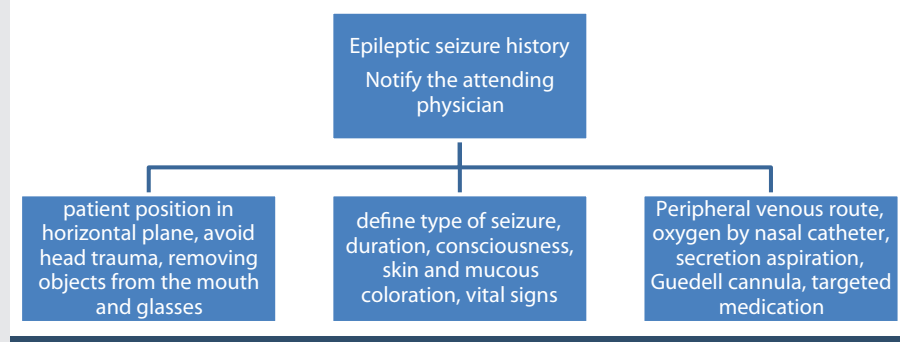

Figure 1: Diagram of the flow of Care of Epileptic Seizure.

- We will control and assess in the patient:

- The duration of the seizure.

- What has consisted of the seizure / type of seizure.

- The level of consciousness.

- The coloring of the skin and mucous membranes.

- We will take vital signs:

- Heart rate.

- Breathing frequency.

- Blood pressure.

- 02 saturation

- We will perform a capillary blood glucose.

- We will put a peripheral road.

- We will administer oxygen with a nasal catheter at two liters / minute and we will aspirate the patient due to the possibility of respiratory secretions.

- We administer medications prescribed by the doctor.

\section{Tonic-clonic onset seizures [34]}

- In those patients with previous epileptic seizures or with significant risk factors in treatment with antiepileptic drugs, severe brain injury, exposure to drugs and hallucinogens, etc.:

- Maintain the necessary material for oxygen therapy and aspiration, in optimal conditions.

- Have a Guedell cannula near the patient (emergency stock).

- Facilitate the accessibility of calls to the nursing staff, especially if there are prodromes.

- Provide a suitable and safe environment, free of furniture and objects that can cause harm during the epilepticseizure.

- Protect the patient from all potentially harmful objects.

- Maintain a patent venous line if necessary. 
- Inform the patient and the family about the action before the appearance of prodromes:

- $\quad$-Remove the teeth or other objects from the mouth.

- Remove the eye lenses.

- Lay him down on the floor or in bed.

\section{During tonic-clonic onset epileptic seizures [35]}

1. Keep calm and serenity as much as possible and we will transmit it to the patient, relatives.

2. Identify that it is a tonic-clonic epileptic seizure.

3. Alert: Notify the doctor on duty.

4. Protect the patient:

- If the patient is out of bed, help him to lie down if possible, or lay him on the floor; avoiding as much as possible the fall.

- Do not leave the patient alone under any circumstances and monitor him.

- Remove nearby objects and / or furniture with which it may hit.

- Loosen clothing that is tight.

- Remove the glasses if you wear them.

- Do not immobilize or restrain the patient by force during the epileptic seizure, but control and guide their movements to avoid injuries.

- Protect the head by placing a pillow or a towel underneath.

5. Guarantee the patency of the airway:

- Remove, if possible, dentures and dental implants that are not permanent.

- Remove food from the mouth in case this process is carried out.

- Insert a Guedell cannula, if possible, but do not do it by force, since we could injure the oral mucosa and / or cause the teeth to break.

- Aspirate secretions, if necessary.

6. Administer oxygen.

7. Put a peripheral line as soon as the seizures stop.

8. Take vital signs:

- Temperature.

- Blood pressure.

- Heart rate.

- Breathing frequency.
9. Carry out the complementary tests requested by the doctor.

10. We will control and assess:

- Duration of the tonic-clonic phase. It is very important, since the severity of the seizure will depend on the duration of it.

- Type of epileptic seizure.

- Where does the movement or begin contracture.

- Eye position and / or eye movements.

- The pupils: relationship between them, size and reactivity.

- Whether or not there is urinary and / or fecal incontinence.

- Time the patient is unconscious.

Procedures and activities in the post-ictal phase of tonicclonic seizures (Figure 2) [32,36-38]:

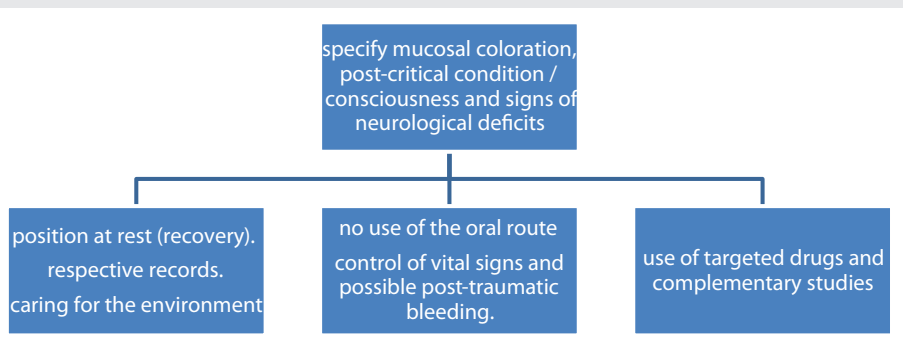

Figure 2: Care Flow Diagram in the post Epileptic Seizure Phase.

1. When the epileptic seizures cease, place the patient in the RECOVERY POSITION.

2. Do not administer anything by mouth.

3. If after the crisis he is excited, calm him down and reassure him. Administer the drug directed by the doctor.

4. If there is any bleeding lesion, press with a sterile compress until the bleeding stops.

5. Ensure that the environment is quiet and safe, without excessive lighting or noise.

6. Carry out a new check of vital signs and serum glycemia.

7. In case of incontinence, proceed to clean the patient.

8. In case of drowsiness, let him rest.

9. When he wakes up, redirect and reassure him.

10. Carry out the complementary tests requested by the doctor.

11. We will control and assess: 
- Duration of the post-seizure phase.

- Assessment of the level of consciousness (GLASGOW SCALE) $[39,40]$.

- Degree of confusion, if he is drowsy, let him sleep and do not wake him up or shake him.

- Color of the skin and / or mucous membranes.

- If the patient can get up.

- Whether he speaks or not. If there is paralysis or weakness in the arms and / or legs.

12. The following will be recorded:

- The vital signs on the vital signs sheet found in the medical record.

- In the nursing evolution sheet and seizure control model (Annex 1): the characteristics and duration of the different phases of the epileptic seizure.

- Apply GLASGOW scale where necessary.

- Report to the nursing department in the registry and report of epileptic seizures (Table 2).

Table 2: Reg: 400 .5. 77(6) epileptic seizure control model.

\begin{tabular}{l|l|l|l|l|} 
Date & hour & Features & Duration & Signature \\
\hline
\end{tabular}

Clinic history:

Patient:

Ward room clinical diagnosis:

\section{Conclusions}

Epilepsy is a disease that carries a significant comorbidity, which can lead to death and therefore social and psychobiological involvement, which is why comprehensive management by health personnel and primarily by nursing staff is necessary.

Specialized protocols must be followed to provide a safe environment and thus avoid injury to patients with epileptic seizures, improving the quality of care for patients with epileptic seizures and thus avoid the appearance of possible complications.

\section{References}

1. Bender JE (2012) Evaluacion clinica pre y postquirurgica de pacientes con epilepsia refractaria. Editorial Universitaria cubana.

2. Bender del Busto JE (2014) Atención al paciente con epilepsia. Edit Univ UNAN-Leon, Nicaragua.

3. Neurological Disorders: Public Health Challenges (2014) Chapter 3. Neurological disorders a public health approach. World Health Organization. Link: https://bit.ly/2G6KLnF
4. Hauser WA, Hesdorffer DC (1990) Epilepsy: frequency, causes and consequences. New York: Demos Press. Link: https://bit.ly/2RVUi3J

5. Maroun F, Fitzgerald W, Rasmussen T, Jacob JC, Sadler M, et al. (1996) Historical vignette: cerebral cortical stimulation and surgery for epilepsy. Can J Neurol Sci 23: 303-307. Link: https://bit.ly/2G6L69V

6. Organizacion Panamericana de la Salud (2008) Informe sobre la epilepsia en latinoamérica. OPS. Link: https://bit.ly/2G3kA1b

7. World Health Organization (2005) Atlas: Epilepsy Care in the World Geneva: World Health Organization. Link: https://bit.ly/3mS5ahm

8. World Health Organization (2014) Neurological Disorders: Public Health Challenges. [Internet] Neurological disorders a public health approach. Link: https://bit.ly/2G6KLnF

9. Mathern G, Nehlig A (2014) From the editors: The discrepancy between accumulative incidence and lifetime prevalence of epilepsy. Epilepsia 55 : 956-957. Link: https://bit.ly/3cvso7U

10. Bell GS, Neligan A, Sander JW (2014) An unknown quantity- The worldwide prevalence of epilepsy. Epilepsia 55: 958-962. Link: https://bit.ly/33S8DU8

11. Jones L, Thomas R (2017) Sudden death in epilepsy: Insights from the last 25 years. Seizure 44: 232-236. Link: https://bit.ly/3420kUp

12. Cascino GD, Buchhalter J (2017) SUDEP. An important cause of premature mortality in epilepsy across the life Spectrum. Neurology 89: 114-115. Link: https://bit.ly/3j3XIxc

13. Shankar R, Donner EJ, McLean B, Nashef L, Tomson T (2017) Sudden unexpected death in epilepsy (SUDEP): what every neurologist should know. Epileptic Disord 19: 1-9. Link: https://bit.ly/331Sz36

14. Lhatoo S, Noebels J, Whittemore V (2015) The NINDS Center for SUDEP Research. Sudden unexpected death in epilepsy: Identifying risk and preventing mortality. Epilepsia 56: 1700-1706. Link: https://bit.ly/366CJGd

15. Devinsky O, Spruill T, Thurman D, Friedman D (2016) Recognizing and preventing epilepsy-related mortality: A call for action. Neurology 86: 779-786. Link: https://bit.ly/3kKjlOs

16. Bender JE (2012) Epilepsia del Lobulo Temporal Refractaria. EAE Editoria Academia Espanola.

17. Maya CM (2010) Epilepsia, Historia y Sociedad. En: Epilepsia. La Habana: Editorial Ciencias Médicas.

18. Jerome E, Timothy P (2008) Introduction: What Is Epilepsy? In: Epilepsy: A Comprehensive Textbook, $2^{\text {nd }}$ Edition. Copyright $\hat{A} \odot 2008$ Lippincott Williams \& Wilkins.

19. Shorvon SD (2009) Drug treatment of epilepsy in the century of the ILAE: The first 50 years, 1909-1958. Epilepsia 50: 69-92. Link: https://bit.ly/3cEL190

20. Shorvon SD (2009) Drug treatment of epilepsy in the century of the ILAE: The first 50 years, 1909-1958. Epilepsia 50: 69-92. Link: https://bit.ly/3cEL190

21. Terra VC, Sakamoto AC (2014) Clasificación de las crisis epilépticas para la programación terapéutica. En: Yacubian EM, Contreras-Caicedo G, Ríos-Pohl L (eds). Tratamiento Farmacológico de las Epilepsias.

22. Fisher RS (2014) practical clinical definition of epilepsy. Epilepsia 55: 475-482. Link: https://bit.ly/335g9Mc

23. Bender JE, Hernández L, Rodríguez L, Menéndez K (2016) Trastornos psiquiátricos asociados a las epilepsias. Revista Habanera de Ciencias Medicas. 15. Link: https://bit.ly/2FTfTaJ

24. Rai D, Kerr MP, McManus S (2012) Epilepsy and psychiatric comorbidity: a nationally representative population-based study. Epilepsia 53: 1095-1103. Link: https://bit.ly/2G6ft0e 
25. Pérez Teodoro P, Martínez MP, Castaño J, Martinez L, Giner P (2013) Actuación de enfermería ante una crisis epiléptica en medio hospitalario y extrahospitalario. Hospital Universitario Dr Peset. Valencia. $14^{\circ}$ Congreso Virtual de Psiquiatria.com. Interpsiquis. Link: https://bit.ly/2G48Zzl

26. Díez B, Fumanal A, Casanovas C, Creus MJ, Molinos MV et al. (2012) Intervención educativa en pacientes con epilepsia ingresados en la Unidad de Monitorización de Epilepsia del Hospital Universitario GermansTrias i Pujol. Revista científica sociedad española enfermería neurológica 35: 12-19. Link: https://bit.ly/3mT7a8T

27. Pérez A, Sánchez JC, Morales MD, Martin M, Sancho J, et al. (2005) Como afrontar la epilepsia. Una guía para pacientes y familiares. Madrid: $1^{\circ} \mathrm{ed}$. Entheos. Link: https://bit.ly/2GaVpdf

28. Bender JE, Hernández TL (2017) Consideraciones en el tratamiento del paciente con epilepsia. Artículo de revisión. Revista Habanera de Ciencias Médicas 16: 912-926. Link: https://bit.ly/3mUCSmk

29. Mercadé JM, Sánchez JC, Galán JM, Moreno V, Serrano PJ, et al. (2009) Guía de práctica clínica de consenso de la Sociedad Andaluza de epilepsia: recomendaciones terapéuticas ante una crisis epiléptica y en el estado epiléptico. Rev Neurol 48: 489-495. Link: https://bit.ly/331taXm

30. Diez B, Cabrera S, Casanovas C, Lopez RM, Fumanal A, et al. (2017) Eficacia de la educación sanitaria a pacientes y familiares en la unidad de monitorización de Epilepsia. Metas Enferm 20: 17-22. Link: https://bit.ly/338DtJn

31. Cano MC (2012) Actualización del cuidado enfermero del paciente con epilepsia. Metas Enferm 15: 15-20. Link: https://bit.ly/369WigP
32. Hernandez L, Peña MA, Miranda L (2015) Actuacion de enfermería ante una crisis epiléptica en el medio hospitalario. Protocolo de actuación. La Habana, Cuba. Centro Internacional de Restauración Neurológica.

33. Herranz JL (2011) Vivir y comprender la epilepsia. Madrid, España. Ergon Creacion, 6a. Link: https://bit.ly/3401nWn

34. Mercadé J (2013) Libro blanco de la epilepsia en España. Madrid, España. INYECCMEDIA S.L.

35. Arroyo S, Campistol J, Comes E, Fossas P, Martínez I, et al. (1999) E tratamiento de las epilepsias. Guía terapéutica Sociedad Catalana de Neurología. Rev Neurol 754-766. Link: https://bit.ly/367oAIY

36. Carmona JV Leiva S (2008) Actuación de enfermería ante una crisis convulsiva en la vía pública. Revista de enfermería integral 29-33. Link: https://bit.ly/2S26m3u

37. Perales M, Moya S (2005) Actuación en urgencias ante una crisis convulsiva en adultos. Emergencias S83-S89.

38. Yusta A (2005) Crisis convulsivas. Concepto, clasificación, etiología Emergencias S68-S73. Link: https://bit.ly/33TCFag

39. Muñana-Rodriguez JE, Ramirez E (2014) Escala de coma de Glasgow: origen, análisis y uso apropiado. Enfermeria Universitaria 11: 24-35. Link: https://bit.ly/3cA1aNx

40. Teasdale G, Allen D, Brennan P, McElhinneyt E, Mackinnon L (2014) The Glasgow Coma Scale: una actualizacion despues de 40 años. Tiempos de enfermería 110: 12-16.

\section{Discover a bigger Impact and Visibility of your article publication with} Peertechz Publications

\author{
Highlights \\ * Signatory publisher of ORCID \\ * Signatory Publisher of DORA (San Francisco Declaration on Research Assessment) \\ - Articles archived in worlds' renowned service providers such as Portico, CNKI, AGRIS, \\ TDNet, Base (Bielefeld University Library), CrossRef, Scilit, J-Gate etc. \\ * Journals indexed in ICMJE, SHERPA/ROMEO, Google Scholar etc. \\ * OAI-PMH (Open Archives Initiative Protocol for Metadata Harvesting) \\ * Dedicated Editorial Board for every journa \\ * Accurate and rapid peer-review process \\ * Increased citations of published articles through promotions \\ * Reduced timeline for article publication \\ Submit your articles and experience a new surge in publication services \\ (https://www.peertechz.com/submission).
}

Peertechz journals wishes everlasting success in your every endeavours.

Copyright: @ 2020 Toledo LH, et al. This is an open-access article distributed under the terms of the Creative Commons Attribution License, which permits unrestricted use, distribution, and reproduction in any medium, provided the original author and source are credited. 